\title{
Illegal Logging and Related Trade: Who Combat It as Legal Subjects?
}

\author{
Jing Qian1,2, Bin $\mathrm{Xu}^{3 *}$, Hongqiang Yang1,2, Ying Nie',4 \\ ${ }^{1}$ College of Economics and Management, Nanjing Forestry University, Nanjing, China \\ ${ }^{2}$ Research Center for Economics and Trade in Forest Products, State Forestry Bureau, Nanjing, China \\ ${ }^{3}$ Research Institute of Forestry Policy and Information, Chinese Academy of Forestry, Beijing, China \\ ${ }^{4}$ Business College, Jinling Institute of Technology, Nanjing, China \\ Email: qj_tracy@126.com, *xubin@caf.ac.cn,yhqnfu@aliyun.com,ynieh@jit.edu.cn
}

Received 23 November 2015; accepted 16 January 2016; published 19 January 2016

Copyright (C) 2016 by authors and Scientific Research Publishing Inc.

This work is licensed under the Creative Commons Attribution International License (CC BY). http://creativecommons.org/licenses/by/4.0/

(C) (i) Open Access

\begin{abstract}
Issue on illegal logging and related trade is a hot topic for the international community. It has brought the negative effects to the sustainable development on global society, economy and ecology, which is also one of the main objectives of international cooperation to combat with. At present, subjects of international law play a decisive role in combating illegal logging and related trade. The subjects of international law generally refer to states, intergovernmental organizations (IGOs) and part of non-governmental organizations (NGOs), which can have an independent international legal personality, enjoy rights and assume obligations of international law. As a responsible big country of the international community and state member of intergovernmental organizations and international treaties of forest resources protection, China ought to fully perform the obligations of international law. In face of illegal logging and related trade around the world, China should rationally tackle with it, resolutely crack down on it, and finally choose the sustainable development strategy based on rule of law.
\end{abstract}

\section{Keywords}

Illegal Logging and Related Trade, Legal Subjects, Rule of Law, Sustainable Forestry Development

\section{Introduction}

In middle and later 1990s, international community began to focus on illegal logging and related trade. The states members fully realize the continuous pressure before forest ecology around the whole world and find out

\footnotetext{
*Corresponding author.
} 
the important value of the sustainable forest management at Group of Eight Meeting held by UK in 1998. For the first time, issues on the illegal logging and related trade being put forward are deemed to be very important. Meetings formally discussed this international problem and formulated G8 Action Program on Forests to combat illegal logging and related trade. Entering into the $21^{\text {st }}$ century, issues on illegal logging and related trade have become the hot topic for the international community.

Illegal logging and related trade are short for illegal timber logging and related international trade of timber and forest products. In a general idea, illegal logging is harvesting, transporting, processing, buying and selling of timber in violation of national laws and regulations (WWF, 1991), and related trade includes transportation, pricing, trading beyond transaction details and other illegal means, which aggravate the harm of illegal logging (Alemagi \& Kozak, 2010; Tumusiime, Vedeld, \& Gombya-Ssembajjwe, 2011; Karsenty, 2003). Illegal logging deprives financial incomes from state and local government, rights and interests from forest owners and local communities (mainly for indigenous people who rely on forest resources). It destructs the forest ecosystem, disrupts the international timber market and forest resources assessment, and hinders the sustainable forest management (Goncalves, Panjer, Greenberg, \& Magrath, 2012; Tacconi, 2007). International trade of timber and forest products tightly related with illegal logging is meanwhile further exacerbating destruction of the forest resources around the world, leading to damage biodiversity and climate change, breeding corruption, weakening the authority of law, impair the safety of country and international community, and ultimately affecting the sustainable development on global society, economy and ecology (Cohen, 1992; Howlett, 1991; Mishra, 2006; Reboredo, 2013).

How to curb the negative effects brought by illegal logging and related trade to the globe? Combating is good. Two successive questions are worth thinking about: 1) who will combat the illegal logging and related trade (i.e. problem on main bodies), and 2) how to combat it. From the perspective of generalized research category, bodies can both implement legally binding behaviors and not (Ertan, Page, \& Putterman, 2009). Bodies who cannot implement legally binding behaviors include industry associations, enterprises, consumers, etc. They are able to combat illegal logging and related trade in their own way (Lawson, 2007; Stahl, 2010). Consumers, for example, use the way of refusing to buy furniture and other wood products probably from illegal logging as a specific forms of combating it. But this research is mainly limited to the bodies of legal binding. Studies have shown that these include states, international inter-governmental organizations and part of non-governmental organizations. It should be pointed out that above bodies are the subjects of international law (Starke, 1994). Subjects of international law, also called international legal person, therefore, are those entities entitled to international legal rights and duties and capable of employing international legal process (Shaw, 2003; Lynch, 2001). Historically, states were the only subjects of international law. In 1949, inter-governmental organizations were confessed as the subjects of international law were based on verdict of "the Reparations Case" returned by the international court of justice. In 1986, member states of European council clearly acknowledged non-governmental organization to be legal personality based on European Convention on the Recognition of the Legal Personality of International Non-Government Organizations (INGOs).

\section{Background and Combating Actions}

Illegal logging is a global issue, affecting most forested countries. In-depth investigations into forestry practices from around the world, as well as research into the timber trade, all indicate that it is a substantial problem (Chatham House, 2010). Therefore, illegal logging and related trade should be curbed by subjects of international law, independent legal personality, under the background of international cooperation.

\subsection{National Level (States)}

Although it is no longer correct that states are the only subject of international law, undoubtedly it is true that states are still the principal subject (Gibson, Ostrom, \& Williams, 2005; Timothy, 1994). The causes why illegal logging and related trade is a serious problem around the world, which can be analyzed that timber-producing countries are lack of effective management to the forest and timber-consuming countries are stimulating the market demands. The government of timber-producing countries will make a larger scale of illegal logging and related trade if there are no corresponding measures to ensure the legitimacy of the imported forest products (Boecher, 2012).

States take unilateral actions against illegal logging and related trade basically having the following three patterns of manifestation on: 1) formulating legal norms with binding sanctions to provide the powerful legal 
protection, 2) adopting green government procurement policy to ensure the legitimacy and sustainability of timber sources, and 3) developing timber legality verification system to ensure the accuracy of timber production and its tracking information and keep the sustainability of sales and exports monitoring.

Obviously most states and their government have clear awareness that they not only need to take their own corresponding actions against illegal logging and related trade, but more bilateral and multilateral agreements and cooperation are needed as well (Table 1). To combat illegal logging and related trade is the responsibility of all countries around the world. United States, Australia, Russia and China formulate or revise the law (especially

Table 1. Actions against illegal logging and related trade of partly states.

\begin{tabular}{|c|c|c|c|}
\hline & Actions & States & Points \\
\hline \multirow{11}{*}{ Unilateral } & Formulate or revise the law & United States & Lacey Act Amendment (2008) \\
\hline & & Australia & Illegal Logging Prohibition Act (2012) \\
\hline & & Russia & $\begin{array}{c}\text { Criminal Code Amendment of Federation (2008) } \\
\text { Roundwood Act (2013) }\end{array}$ \\
\hline & & China & Section 4, Criminal Law Amendment Act (2002) \\
\hline & Green Government Procurement & $\begin{array}{l}\text { United } \\
\text { Kingdom }\end{array}$ & $\begin{array}{l}\text { Timber, wood and paper products from legitimate and } \\
\text { sustainable sources or Forest Law Enforcement, } \\
\text { Governance and Trade (FLEGT) certification (2009) }\end{array}$ \\
\hline & & France & $\begin{array}{l}\text { Timber and wood products from legitimate and sustainable } \\
\text { sources and Convention on International Trade in } \\
\text { Endangered Species of Wild Fauna and Flora (CITES) (2005) }\end{array}$ \\
\hline & & German & $\begin{array}{l}\text { Timber and wood products from Forest Stewardship Council } \\
\text { (FSC) certification (2010) }\end{array}$ \\
\hline & & Japan & Timber, wood and paper products from legitimate sources (2006) \\
\hline & & Switzerland & $\begin{array}{l}\text { Timber and wood products from FSC certification or } \\
\text { Programmme for the Endorsement of } \\
\text { Forest Certification (PEFC) (2005) }\end{array}$ \\
\hline & Timber Legality Verification & Indonesia & Timber Legality Assurance System (TLAS, 2013) \\
\hline & & Switzerland & Mandatory Legal Timber Validation (MLTV, 1995) \\
\hline \multirow{5}{*}{ Bilateral } & Consultation and Dialogue & Sino-US & $\begin{array}{l}\text { Topic of Strategic and Economic Dialogue (SED, 2007) } \\
\text { Memorandum of Understanding (MOU, 2008) } \\
\text { Five forums (2008, 2009, 2010, 2012, 2013) }\end{array}$ \\
\hline & Forums and Agreements & Sino-Russia & $\begin{array}{c}\text { Consensus to strengthen crackdown on illegal logging and } \\
\text { associated trade at the 10th regular meeting } \\
\text { of two Prime Ministers (2005) }\end{array}$ \\
\hline & & Sino-Indonesia & Memorandum of Understanding (MOU, 2002) \\
\hline & & Sino-Australia & $\begin{array}{l}\text { Memorandum of Understanding and } \\
\text { Working Group establishment (2009) }\end{array}$ \\
\hline & & Sino-Japan & Memorandum of Understanding (MOU, 2010) \\
\hline \multirow{5}{*}{ Multilateral } & Group 8 (G8) Summit & G8 & $\begin{array}{l}\text { G8 Action Program on Forests, first commitment to } \\
\text { combat illegal logging and associated trade (1998) }\end{array}$ \\
\hline & $\begin{array}{l}\text { Asia-Pacific Economic } \\
\text { Cooperation (APEC) }\end{array}$ & Member States & $\begin{array}{l}\text { Experts Group establishment (2011) } \\
\text { Five Expert Group meetings (2012, 2013, 2014) }\end{array}$ \\
\hline & $\begin{array}{l}\text { Forest Law Enforcement and } \\
\text { Governance (FLEG) }\end{array}$ & $\begin{array}{c}\text { Benefit } \\
\text { Countries }\end{array}$ & Asian Ministerial Conference at Bali, Indonesia (2001) \\
\hline & & & African Ministerial Conference at Yaounde, Cameroon (2003) \\
\hline & & & $\begin{array}{l}\text { European and North-African Ministerial } \\
\text { Conference at Petersburg, Russia (2005) }\end{array}$ \\
\hline
\end{tabular}


criminal law) to enhance the punishment on activities of illegal logging. Among these laws, the most famous one is Lacey Act Amendment, which provides a good demonstration to other countries. Green Government Procurement is also used by United Kingdom, France, German, Japan and Switzerland to make timber, wood or paper products form legitimate and sustainable sources. Timber legality verification is another effective way for Indonesia and Switzerland to guarantee the using of legal timber. On the bilateral aspect, through dialogue, forum and agreement, China keeps the good relationship with other forested countries to combat illegal logging and related trade. In the international society, G8, APEC and FLEG member states or benefit countries focus the problem based on the state-level conference or meeting. In all, the government of lumber producers, importers and consumer, only through bilateral or multilateral cooperation, can effectively combat illegal logging and related trade (Brack \& Hayman, 2002).

\subsection{Inter-Governmental Organizations (IGOs)}

According to the traditional theory of international law, IGO is defined as a permanent organization composed primarily of sovereign states to seek cooperation and achieve the goal of common interest (Shao, 2000). The role of IGO in the world order centers on their possession of international legal personality. Once this is established, they become subjects of international law and thus capable of enforcing rights and duties (Shaw, 2003).

\subsubsection{United Nations (UN)}

The UN, as the most universal, representative and authoritative inter-governmental organization, is the most important platform to practice multilateralism (Lawson \& MacFaul, 2010). According to Charter of the United Nations, the purposes of UN are to maintain international peace and security, to develop friendly relations among nations, to achieve international co-operation in solving international problems of an economic, social, cultural, or humanitarian character and to be a centre for harmonizing the actions of nations in the attainment of these common ends. Due to its unique international character, and the powers vested in its founding Charter, the Organization can take action on a wide range of issues, and provide a forum for its 193 Member States to express their views, through the General Assembly, the Economic and Social Council, Secretariat, International Court of Justice, and other bodies and committees.

Close attention is paid to the forest issues on illegal logging and related trade by the UN, which is divided into organs and conventions system. The bodies of UN contributed to forestry sustainable development or forest resources protection are UN General Assembly, Economic and Social Council (ECOSOC), Secretariat and International Court of Justice. In the conventions system, international conventions or treaties of human rights, environment and trade are involved in illegal logging and related trade. Thus, at present, these organs and conventions mentioned above in UN system concretely include the United Nations Forest Forum (UNFF), United Nations Environment Programme (UNEP), United Nations Food and Agriculture Organization (FAO), United Nations Development Programme (UNDP), United Nations Office on Drugs and Crime (UNODC), World Bank Group (WBG), United Nations Convention on Biological Diversity (CBD), United Nations Convention to Combat Desertification (UNCCD), United Nations Framework Convention on Climate Change (UNFCCC), Convention on International Trade in Endangered Species of Wild Fauna and Flora (CITES) (Figure 1).

\subsubsection{International Criminal Police Organization (INTERPOL)}

The INTERPOL, established in 1923 as the International Criminal Police Commission, is the second largest intergovernmental organizations except for the United Nations. Today, the INTERPOL has a global membership of 190 countries. The role is to enable police around the world to work together to make the world a safer place. Its high-tech infrastructure of technical and operational support helps meet the growing challenges of fighting crime in the 21st century. INTERPOL points out that illegal trade in wildlife and timber products finances criminal and militia groups, threatening security and sustainable development (INTERPOL \& UNEP, 2012).

A report-Green Carbon, Black Trade-by UNEP and INTERPOL was published to especially focus on illegal logging and its impacts on the lives and livelihoods of often some of the poorest people in the world set aside the environmental damage in 2012. It shows that in spite of certification and management efforts, illegal logging has not stopped. Indeed it has remained high in many regions including the Amazon, Central Africa and Southeast Asia. In some areas, it has actually increased in recent years (Brack, 2003; INTERPOL \& UNEP, 2012). The report provides an overview of how illegal logging takes place, describes common methods of how it is laundered 


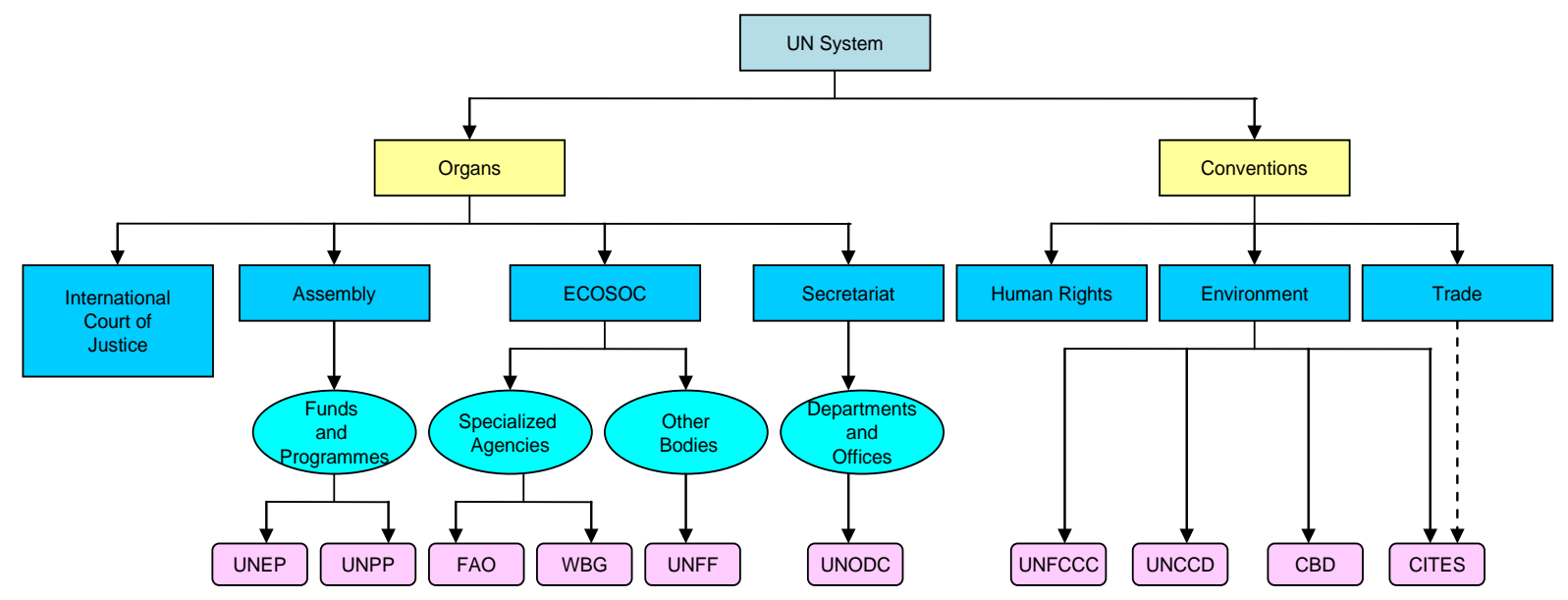

Figure 1. Framework of the United Nations System related with issues on illegal logging and related trade.

and financed and its primary destinations, reviews some of the current practices and initiatives to combat illegal logging and makes the recommendations on how to effectively fight against criminal activities associated with illegal logging. The conclusion is made to sure that including the development of a full-fledged Law Enforcement Assistance to Forests (LEAF) programme under INTERPOL and UNEP, the whole world needs to undertake coordinated international and improved national law enforcement and investigative efforts to reduce illegal logging.

\subsubsection{World Customs Organization (WCO)}

The WCO, established in 1952 as the Customs Co-operation Council, is an independent inter-governmental organization whose mission is to enhance the effectiveness and efficiency of Customs administrations. Today, the WCO represents 179 Customs administrations across the globe that collectively process approximately 98\% of world trade. The vital role is to play in stimulating the growth of legitimate international trade. By promoting the emergence of an honest, transparent and predictable Customs environment, the WCO directly contributes to the economic and social well-being of its Members. In an international environment characterized by instability and the ever-present threat of terrorist activity, the WCO's mission to enhance the protection of society and the national territory, and to secure and facilitate international trade, takes on its full meaning (López-Casero \& Scheyvens, 2010).

The WCO Regional Intelligence Liaison Office for Asia and the Pacific (RILO A/P) serves as a most promising platform to systematically carry out customs cooperation among the member states against illegal logging and related trade. The WCO, therefore, is calling on member states to provide information about illegal timber trade to RILO A/P and make full use of Environet, a new WCO initiative, to exchange information about cargos and documents of suspicious timber through cooperation between the Customs and other departments. Meanwhile, the WCO develops two models-the Model Bilateral Agreement and the Model Memorandum on Mutual Administrative Assistance in Customs Matter-to promote the comprehensive communication between member states and to ensure the application of customs law and prevention of crime including the illegal trade in timber (López-Casero \& Scheyvens, 2010).

\subsubsection{European Union (EU)}

The EU, unlike the IGOs mentioned above, is a regional inter-governmental organization. It is a unique economic and political partnership between 28 European countries that together cover much of the continent. What began as a purely economic union has evolved into an organization spanning policy areas, from development aid to environment. The EU is based on the rule of law: everything that it does is founded on treaties, voluntarily and democratically agreed by all member countries. These binding agreements set out the EU's goals in its many areas of activity (Bouriaud, 2005).

In order to resolutely combat illegal logging, the EU initiates to the FLEGT Action Plan. FLEGT stands for Forest Law Enforcement, Governance and Trade, and its Plan established in 2003 is composed of two parts, the EU Timber Regulation (EUTR) and Voluntary Partnership Agreements (VPA). It aims to reduce illegal logging 
by strengthening sustainable and legal forest management, improving governance and promoting trade in legally produced timber.

The EUTR is binding legislation that the EU has introduced to reduce illegal logging in the world's forests. It adopted came into force on March 3 2013. Under the regulation, it prohibits operators in Europe from placing illegally harvested timber and products derived from illegal timber on the EU market. "Legal timber" is defined as timber produced in compliance with the laws of the country where it is harvested (EFI, 2013). The regulation applies to timber and a wide range of timber products, including pulp and paper.

A VPA is a legally binding trade agreement or bilateral between the European Union and a timber-producing country outside the EU. Under this agreement, the timber-producing country agrees to control and license its exports as legal, and the EU agrees to accept only licensed imports based on strong Timber Legality Assurance Systems (TLAS) from that country. The purpose of a VPA is to ensure that timber and timber products exported to the EU come from legal sources (EFI, 2013). The agreements also help timber-exporting countries stop illegal logging by improving regulation and governance of the forest sector.

\subsubsection{International Tropical Timber Organization (ITTO)}

The ITTO is an inter-governmental organization promoting the conservation and sustainable management, use and trade of tropical forest resources. However, it occupies an unusual position in the family of intergovernmental organizations. Like all commodity organizations it is concerned with trade and industry, but like an environmental agreement it also pays considerable attention to the sustainable management of natural resources.

It mainly develops internationally agreed policy documents to promote sustainable forest management and forest conservation and assists tropical member countries to adapt such policies to local circumstances and to implement them in the field through projects. Its members including producing and consuming countries represent about $80 \%$ of the world's tropical forests and $90 \%$ of the global tropical timber trade (Carle \& Holmgren, 2008).

It is the implementation and management agency of International Tropical Timber Agreement (ITTA), concerning over different topics on tropical forests in 1983, 1994 and 2006. The ITTA of 2006 (entered into force on December 7, 2011) builds on the foundations of the previous agreements, focusing on the world tropical timber economy and the sustainable management of the resource base, simultaneously encouraging the timber trade and the improved management of the forests (ITTO, 2006). The objectives are to promote the expansion and diversification of international trade in tropical timber from sustainably managed and legally harvested forests and to promote the sustainable management of tropical timber producing forests by providing an effective framework for consultation, international cooperation and policy development among all members with regard to all relevant aspects of the world timber economy; ...improving marketing and distribution of tropical timber and timber product exports from sustainably managed and legally harvested sources and which are legally traded, including promoting consumer awareness; ....strengthening the capacity of members to improve forest law enforcement and governance, and address illegal logging and related trade in tropical timber... identifying and addressing relevant new and emerging issues (UNDP, 2008).

\subsection{Non-Governmental Organizations (NGOs)}

As a legal concept, NGO is defined as "any international organizations which is not established by inter-governmental agreement”, Resolution 288 (x) UNECOSOC in 1950. International judicial practice shows that NGOs widely participate in various international affairs and plays a positive role since 1980s. This reality can explain why some NGOs inevitably become the subjects of international law. In recent years NGOs plays an important role in combating illegal logging and related trade and promoting sustainable forest management (Table 2). Chatham House, the very earlier NGO established in 1920, aims to develop sustainable projects about legally international trade of forest products through assessing the current situation of illegal logging and related trade around the world. After that, various kinds of NGO for forest sustainable development or its associated affairs continuously have come to appear. The purpose of IUCN is to support forested countries in combating illegal logging and related trade. As a large and famous NGO, WWF is working hard for a long period of time to protect the natural environment including GFTN to prohibit illegal logging around the world, while Greenpeace is trying to deal with the problem on excessive and illegal logging in the tropical forest or virgin forest. IIED is 
Table 2. NGOs’ contribution to combat illegal logging and related trade.

\begin{tabular}{|c|c|c|c|}
\hline Organization & & Establishment & Involvement Area \\
\hline Chatham House & / & 1920 & $\begin{array}{l}\text { Developing sustainable development projects to focus on } \\
\text { legal and sustainable international trade of forest products } \\
\text { from producing and consuming countries } \\
\text { - Assessing the scale and effectiveness of the response to } \\
\text { illegal logging and the related trade around the world }\end{array}$ \\
\hline $\begin{array}{l}\text { International Union for } \\
\text { Conservation of Nature }\end{array}$ & IUCN & 1948 & $\begin{array}{l}\text { - Supporting countries to participate in combating illegal } \\
\text { logging and related trade and promoting sustainable } \\
\text { forest management }\end{array}$ \\
\hline World Wild Fund & WWF & 1961 & $\begin{array}{l}\text { - Developing Global Forest Trade Network (GFTN)to prohibit } \\
\text { illegal logging around the world } \\
\text { - Driving the reliable forest certification } \\
\text { - Protecting the biological diversity } \\
\text { - Promoting the sustainable and harmonious development of } \\
\text { man and nature }\end{array}$ \\
\hline Greenpeace & / & 1971 & $\begin{array}{l}\text { - Developing forest project to protect the earth's last remaining } \\
\text { virgin forest and its people, animals and plants }\end{array}$ \\
\hline $\begin{array}{l}\text { International Institute of } \\
\text { Environment and } \\
\text { Development }\end{array}$ & IIED & 1971 & $\begin{array}{l}\text { Continuous research on climate change, natural resource } \\
\text { management and sustainable market issues to provide } \\
\text { opinions and suggestions to the government, enterprises } \\
\text { and international development agencies }\end{array}$ \\
\hline $\begin{array}{l}\text { Environmental Investigation } \\
\text { Agency }\end{array}$ & EIA & 1984 & $\begin{array}{l}\text { - Focusing on illegal and destructive logging and forest } \\
\text { destruction caused by illegal trade by environmental crime } \\
\text { investigation and exposure }\end{array}$ \\
\hline Global Witness & / & 1993 & $\begin{array}{l}\text { - Carrying out independent research and lobbying work to } \\
\text { focus on regional conflicts, corruptions and human rights } \\
\text { issues caused by illegal trade in forest products }\end{array}$ \\
\hline $\begin{array}{l}\text { Center for International } \\
\text { Forestry Research }\end{array}$ & CIFOR & 1993 & $\begin{array}{l}\text { - Focusing on sustainable development of developing countries } \\
\text { through strategic and applied research cooperation }\end{array}$ \\
\hline & & & $\begin{array}{l}\text { - Paying special attention to forest protection and people's } \\
\text { livelihood in tropical countries }\end{array}$ \\
\hline Forest Trends & / & 1999 & $\begin{array}{l}\text { - Accomplishing the target of forest protection and sustainable } \\
\text { development by means of market and multi-party cooperation }\end{array}$ \\
\hline $\begin{array}{l}\text { Global Environmental } \\
\text { Institute }\end{array}$ & GEI & 2004 & $\begin{array}{l}\text { - Solving environmental problems guided with market } \\
\text { - } \quad \text { Realizing the comprehensively sustainable development }\end{array}$ \\
\hline European Forest Institute & EFI & 2007 & $\begin{array}{l}\text { - Supporting EU and its members, developing countries and } \\
\text { forestry stakeholder to implement the FLEGT Action Plan } \\
\text { against illegal logging and related trade }\end{array}$ \\
\hline
\end{tabular}

inclined to provide opinions or make suggestions about forest resource management to governments and enterprises. EIA is established to conduct environmental crime investigation to combat the illegal or destructive logging and related trade. Global Witness is carrying out independent research to focus other social problems, such as regional conflicts, corruptions and human rights issues, caused by illegal trade in forest products. CIFOR and Forest Trends are very helpful in building the good relationship or cooperation system among governments and research agencies to promote the forest sustainable development strategy. In the $21^{\text {st }}$ century, the objective of GEI, a local NGO in China, is using market mechanism and policy suggestions to solve environmental problems and to win more social, environmental and economic benefits. EFI is a regional institution specially founded for battle against illegal logging and related trade, which has supported EU and its members, developing countries and forestry stakeholder to implement the FLEGT Action Plan. However, it should be pointed out that the NGOs cannot be all certain of their statues of subjects of international law. The exact conclusion remains to be argued. 


\section{China’s Attitude toward Illegal Logging}

"The Clash of Civilizations and the Remaking of World Order" points out that the rise of China will make it be the largest economy of the world in early $21^{\text {st }}$ century, which is the basis of theoretical hypothesis of "Chinese Hegemony”. The US-led western countries, for a long time are in an attempt to split China territorially, subversive China politically, contain China strategically, and thwart China economically (Huntington, 1998). Some scholars put forward recently, illegal logging is a new word constructed by developed countries and their controlled IGOs and NGOs. If China will make itself enter into the present political discourse system of illegal logging, it is bounded to harm national interests (Liu, Long, \& Tu, 2014). Such concerns have a point, but China, as one of the six major powers in the international system at the end of the cold war (Henry, 1994), state member of inter-governmental organizations mentioned above and international treaties of forest resources protection, in the face of illegal logging and related trade on a global scale bringing to the negative impact on social, economic and ecological sustainable development, shall fully perform the obligations of international law, set up the image of a responsible big country and rationally tackle with illegal logging and related trade issues (Figure 2). China is known to the world in view of its vast painting, large population and rapid economic development. Based on these characteristics, at present in the field of timber consumption, China has become the largest importer of timer and the second biggest importer of forest products in the worldwide, which undoubtedly makes China become a big country due to its large scale of forestry products trade. On the contrary, China is also a country of its per-capita forest area, stocking volume lag and forest coverage rate far behind from the world's average level. Accompanied with the lack of forest resources problem, for a long time, China is suffering attention and criticism on the issue of illegal logging and related trade. However, as a big country, China is conducting the effective plans and programs to relieve the severe situation of timber utility. No matter what to be implemented to combat illegal logging and related trade, strategy of sustainable development should be followed up to guide different actions. How to unremittingly persist in the route of forestry sustainable development? China has found out a solution to promote it, that is, rule-of-law concept and principle, which also corresponds to Chinese national governance policies today.

\subsection{Contradiction between Scarce Forest Resources and Rigid Timber Demands}

With sustained and rapid development of economy, China has become a big country due to its large scale of forest products trade. Woody forest products trade is growing rapidly, from $\$ 14.185$ billion in 2000 to $\$ 80.96$ billion in 2011. The average annual growth rate is $17.16 \%$, and the proportion of the world wood forest products

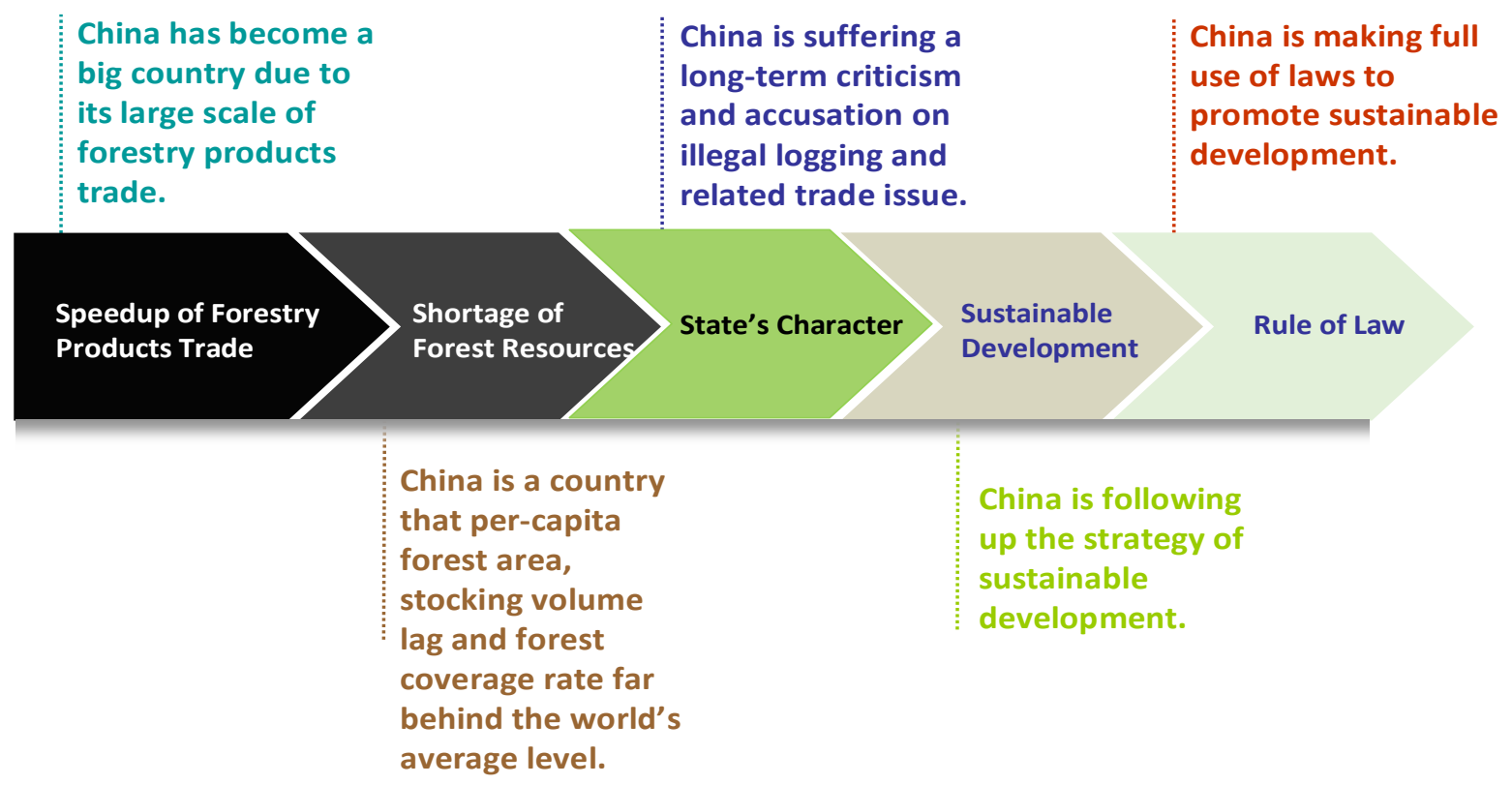

Figure 2. Logical framework to show why and how China combats illegal logging and related trade. 
trade is from $2.51 \%$ growth in 2000 to $8.42 \%$ in 2011 (SFA, 2012). 2013 is the first year after the " $18^{\text {th }}$ Party Congress". In the situation of structural adjustment to promote growth, China's economic development is totally good, especially the real estate industry is being better. The area of commercial housing sales for the whole year was substantial, in the same period, 4.6 million sets of economic affordable housing were completed and put into use. The healthy development of real estate industry promotes the development of wood processing industry and forest product trade. According to the statistics, between January 2013 and December 2013, the national import and export gross of forest products was amount to $\$ 125.991$ billion (GAC, 2014).

At the same time, China is also a country with shortage of forest resources. According to the 8th National Forest Resources Inventory (2009-2013), the national forest area is 208 million hectares, ranking 5th in the world; stocking volume lag is 15.137 billion cubic meters, ranking 6th in the world; forest coverage rate is $21.63 \%$. However, China's per-capita possession of forest area is of $25 \%$ less than the world average level (0.62 hectares), per-capita stocking volume lag is equivalent to $13 \%$ of the world's per-capita volume (68.54 cubic meters), the forest coverage rate is far lower than the world average level (31\%). In 1998, the government launched the "Natural Forest Protection Programme" (NFPP). NEPP plays an important role to restore the forest ecology and leads to reduce the domestic supply of timber resources.

It is almost difficult to reconcile the contradiction between rigid timber demands and scarce forest resource in a short term. At present, the problem on balance of timber supply and demand is being solved mainly by international import (Han, Tian, Cai, Yu, \& Tian, 2013). Zhao (2014), former chief of the State Forestry Administration, pointed out in press conference of the State Council that currently China's external dependence of wood was up to $50 \%$ according to the 8th National Forest Resources Inventory. The contradiction between forest effective supply and increasing social demand is still outstanding.

\subsection{Firm Stance in Face of Illegal Logging and Related Trade}

In recent years, China is suffering criticism from other countries and NGOs in the role of international forest products trade including illegal logging and related trade. For example, the EIA released a report entitled "Appetite for destruction: China's trade in illegal timber" in 2012. The report points out that China is not only the world's largest importer, consumer and exporter of timber and forest products, but the world's largest country of illegal timber trade as well. Nearly $20 \%$ of the imported wood is from illegal timber resources, equivalent to the illegal timber of $\$ 6.9$ billion entering into China each year. The increasing growth of imported timber demand in China will be the main cause of illegal logging problem existed eventually in some countries (EIA, 2012).

The Government puts forward seven principles to combat illegal logging and related trade, which is to show the firm stance of Government in face of world public opinion (Li, Sun, Xie, Zhong, \& Wang, 2009). They are to: adhere to the principle of national sovereignty; adhere to the principle of government leading; adhere to the principle of strengthening sustainable forest management; adhere to the principle of protecting the normal international trade; adhere to the principle of global cooperation; adhere to the principle of scientific definition, assessment and report; adhere to the principle of community participation and earnings (SFA, 2007).

\subsection{Sustainable Development and Rule of Law}

The positive goal of international cooperation combating illegal logging and related trade is to promote the sustainable development of forest resources and environment (Boyle \& Freestone, 1999; UNDP, 2008). Sustainable development is closely related with the rule of law. To promote the rule of law is one of the main goals of the UN system. The past 40 - 50 years, legal statue of development suggests that national and international levels of environmental law can make great contributions to promoting to establish a lasting partnership between the environmental protection and sustainable development on ecology, economy and society. The main task of rule of law is to identify the sustainable development in the 21st century.

The standard ability, impartiality, authority, enforceability and remediability of the law make it sure that the rule of law is the fundamental guarantee to realize sustainable development strategy. The reason is that law itself has the special functions: 1) Legal provision has the authoritative norms, standards and procedures to promote each resolution effectively implemented, 2) A fair, stable and predictable legal framework plays an important role to ensure sustainable development, 3) A law gives a special authorization to statutory bodies, which the inclusiveness, transparency, accountability and good governance of such institutions is to protect social vulnerable groups, and 4) Legal system itself provides a variety of selection mechanism to take intervention measures. 


\section{Conclusion}

When the international community began to focus on illegal logging and related trade, the question on how to combat it is highly attended. On the contrary, it is illustrated and demonstrated inadequately who are combating illegal logging and related trade, especially the subjects of legal binding.

According to the theory of international law, international legal relationship is composed of three basic elements. They are the subjects, objects and contents. If combating illegal logging and related trade is seemed to be formed a sort of international legal relationship, the subjects are states, inter-governmental organizations and part of non-governmental organizations, the objects are a series of behaviors of illegal logging and related trade, and the contents are rights and obligations that the subjects should share and assume. It is obvious that the subject of international law is the logical starting point and theoretical basis to talk about the issues on the international legal relationship of combating illegal logging and related trade. Therefore, this research breaks through the existing research framework and train of thought, and has important theoretical value and practical significance with the perspective of position and role of subjects of international law to focus on illegal logging and related trade.

Also, as it is mentioned in above paper, member states of European council clearly acknowledged non-governmental organization to be legal personality based on European Convention on the Recognition of the Legal Personality of International Non-Government Organizations in 1986. In Table 2, lots of NGOs are listed to show that they are focusing on illegal logging and related trade. However, not all the NGOs are the subjects of international law. The exact conclusion remains to be specified by the following research.

\section{Acknowledgements}

The authors would like to take this opportunity to acknowledge the Research Center for Economics and Trade in Forest Products of the State Forestry Administration (SINO-RCETFOR) and Department of Law, College of Economics and Management, Nanjing Forestry University (NFU) for providing support for the research. All persons helping us finish this paper are deeply appreciated.

\section{References}

Alemagi, D., \& Kozak, R. A. (2010). Illegal Logging in Cameroon: Causes and the Path Forward. Forest Policy and Economics, 12, 554-561. http://dx.doi.org/10.1016/j.forpol.2010.07.008

Boecher, M. (2012). A Theoretical Framework for Explaining the Choice of Instruments in Environmental Policy. Forest Policy and Economics, 16, 14-22. http://dx.doi.org/10.1016/j.forpol.2011.03.012

Bouriaud, L. (2005). Causes of Illegal Logging in Central and Eastern Europe. Small-Scale Economic Manage Policy, 4 , 269-292.

Boyle, A., \& Freestone, D. (1999). International Law and Sustainable Development. Oxford: Oxford University Press.

Brack, D. (2003). Illegal Logging and the Illegal Trade in Forest and Timber Products. International Forestry Review, 5 , 195-198. http://dx.doi.org/10.1505/IFOR.5.3.195.19148

Brack, D., Gray, K., \& Hayman, G. (2002). Controlling the International Trade in Illegally Logged Timber and Wood Products. London: Royal Institute of International Affairs.

Carle, J., \& Holmgren, P. (2008). Wood from Planted Forests: A Global Outlook 2005-2030. Forest Products Journal, 58, 6-18.

Chatham House (2010). Illegal Logging Portal: Scale of Illegal Logging. London: Royal Institute of International Affairs.

Cohen, M. A. (1992). Environmental Crime and Punishment: Legal/Economic Theory and Empirical Evidence on Enforcement of Federal Environmental Statutes. Criminal Law, 82, 1054-1108. http://dx.doi.org/10.2307/1143716

EFI (2013). What is Illegal Logging? Joensuu: European Forest Institute.

EIA (2012). Appetite for Destruction: China's Trade in Illegal Timber. London: Environmental Investigation Agency.

Ertan, A., Page, T., \& Putterman, L. (2009). Who to Punish? Individual Decisions and Majority Rule in Mitigating the Free Rider Problem. European Economic Review, 53, 495-511. http://dx.doi.org/10.1016/j.euroecorev.2008.09.007

GAC (2014). National Import and Export Data of Forest Products. Beijing: General Administration of Customs.

Gibson, C., Ostrom, E., \& Williams, J. (2005). Local Enforcement and Better Forests. World Development, 33, $273-284$. http://dx.doi.org/10.1016/j.worlddev.2004.07.013 
Goncalves, M. P., Panjer, M., Greenberg, T. S., \& Magrath, W. B. (2012). Justice for Forests: Improving Criminal Justice Efforts to Combat Illegal Logging. Washington, DC: World Bank Group. http://dx.doi.org/10.1596/978-0-8213-8978-2

Han, M. X., Tian, M. H, Cai, X. Y., Yu, H. L., \& Tian, H. W. (2013). Discussion on the Correlation between Chinese Woody Products Trade and International Illegal Logging. Forestry Economics, 9, 75-83.

Howlett, M. (1991). Policy Instruments, Policy Styles and Policy Implementation. Policy Studies Journal, 19, 1-21. http://dx.doi.org/10.1111/j.1541-0072.1991.tb01878.x

Huntington, S. P. (1998). The Clash of Civilizations and the Remaking of World Order. New York: Georges Borchardt, Inc.

INTERPOL, \& UNEP (2012). Green Carbon, Black Trade: Illegal Logging, Tax Fraud and Laundering in the Worlds Tropical Forests. Vienna: INTERPOL Environmental Crime Programme.

ITTO (2006). International Tropical Timber Agreement. Yokohama: International Tropical Timber Organization.

Karsenty, A. (2003). Underlying Causes of the Rapid Expansion of Illegal Exploitation of Tropical Timber. International Forestry Review, 5, 236-239. http://dx.doi.org/10.1505/IFOR.5.3.236.19136

Lawson, S. (2007). Illegal Logging and Related Trade: Measuring the Global Response. London: Chatham House.

Lawson, S., \& MacFaul, L. (2010). Illegal Logging and Related Trade: Indicators of the Global Response. London: Chatham House.

Li, G. M., Sun, J. L., Xie, M. D., Zhong, Y. F., \& Wang, G. X. (2009). International Discussion on Illegal Logging and Counter Measures of China. Topical Forestry, 37, 17-20.

Liu, J. L., Long, H. X., \& Tu, C. Y. (2014). Action Analysis of Major Stakeholders under the Discourse of Illegal Logging. Forestry Economics, 3, 83-89.

López-Casero, F., \& Scheyvens, H. (2010). Customs Collaboration to Combat the International Trade in Illegal Timber. London: Environmental Investigation Agency Policy Brief.

Lynch, O. (2001). Mandating Recognition: International Law and Native/Aboriginal Title. Washington DC: The Rights and Resources Initiative.

Mishra, A. (2006). Persistence of Corruption. World Development, 4, 349-358. http://dx.doi.org/10.1016/j.worlddev.2005.03.010

Reboredo, F. (2013). Socio-Economic, Environmental, and Governance Impacts of Illegal Logging. Environment Systems \& Decisions, 33, 295-304. http://dx.doi.org/10.1007/s10669-013-9444-7

SFA (2007). The Report of China's Forest Law Enforcement and Administrative Management. Beijing: State Forestry Administration.

SFA (2012). The Report of China Forestry Development. Beijing: State Forestry Administration.

Shao, J. (2000). International Law. Beijing: Peking University Press.

Shaw, M. N. (2003). International Law (8th Revised Edition). London: Cambridge University Press.

Stahl, J. (2010). The Rents of Illegal Logging: The Mechanisms behind the Rush on Forest Resources in Southeast Albania. Conservation Society, 8, 140-150. http://dx.doi.org/10.4103/0972-4923.68916

Starke, J. G. (1994). International Law. Oxford: Butterworth-Heinemann publications.

Tacconi, L. (2007). Illegal Logging: Law Enforcement, Livelihoods and the Timber Trade. London: Earthscan.

Timothy, H. (1994). Principles of Public International Law. London: Routledge Cavendish.

Tumusiime, D. M., Vedeld, P., \& Gombya-Ssembajjwe, W. (2011). Breaking the Law? Illegal Livelihoods from a Protected Area in Uganda. Forest Policy and Economics, 13, 273-283. http://dx.doi.org/10.1016/j.forpol.2011.02.001

UNDP (2008). Human Development Report, 2007-2008. New York: United Nations Development Program.

WWF (1991). What's GFTN? WWF's Initiative to Eliminate Illegal Logging. Gallon: World Wide Fund for Nature.

Zhao, S. C. (2014). Press Conference on the Results of Eighth National Forest Resources Inventory. Beijing: State Council. 